\title{
Using critical pedagogies from adult education to inspire and challenge higher education students
}

\author{
KARIMA KADI-HANIFI
}

\begin{abstract}
This interdisciplinary paper is about applying Adult Education methods of learning and teaching to higher education. I argue that higher education students need to be stimulated via interactive methods that improve their motivation and lead them to question the value system/s that exist around them. A Freirean approach as used in the teaching of Adult Literacy and English for Speakers of Other Languages (ESOL) was applied to a group of 'elite' students at the University of Birmingham who were taking a language foundation course. As a sociolinguist and ESOL practitioner from a black perspective, I argue that the understanding of concepts of language and racism, imperialism and social class can best be facilitated using such an approach. Taking groups of students through this learning journey is challenging for higher education practitioners and the results add a relatively new dimension to the collective reflection on learning and teaching in higher education today.
\end{abstract}

KEYWORDS

adult education, English for Speakers of Other Languages, Freire, higher education, imperialism, racism, social class, sociolinguistics

\section{Introduction and the critical pedagogy tradition in post-com- pulsory education}

In this paper, I propose that adult education teaching methods (as defined by Petty 2004; Curzon 1990; Rogers 1997) could benefit higher education. I carried out the post-course reflective research on my teaching and learning practice, detailed in this paper, after joining the University of Birmingham in the spring term of 2006. I had been asked 
to substitute for a lecturer on study leave, teaching linguistics on a first year language foundation course in the Department of English. I ran 10 weekly sessions with two different groups of first year English Literature students on aspects of sociolinguistics. The spring term of 2006 turned out to be a critical moment or shake-up for me, from teaching at the 'coal face' to reflecting on how to use that teaching and learning experience in a more conventional teaching context.

As I was emerging from a recent career in adult and further education, I wanted to use some of the methods that I had learned in those sectors - methods which empower students to want to change themselves and then change their environment/s and social context/s. My induction into teaching adults, in the Sheffield of the mid 1980s, was very basic but significant. I was given a flipchart pen and Paulo Freire's book, Pedagogy of the Oppressed, first published in English in 1970. I was then told to just go and teach by responding to what the students needed. It is worth noting that, although his work is not as explicitly highlighted as it used to be in the past, Freire still has a huge following nowadays, mainly in community-based programmes within adult and further education. In my subject specialism of ESOL, Freire's influence is certainly still there today, even though the target-driven way in which adult and further education are going does not always allow for his approach to be of primary importance and certainly not in some of the ESOL programmes in which the outcomes are more and more focused on employability as a response to the Leitch Review of Skills (2006). However, much of what is now called Skills for Life and which include Adult Literacy, ESOL and Numeracy is still delivered in community settings and at levels that are not yet able to match the employability targets of funding bodies. Employability targets are not always appropriate, for example, for Skills for Life programmes that target students with low levels of literacy, ESOL and numeracy. Employability targets have led to either a reduction in community provision where locally negotiated schemes of work, based on soft targets (i.e., non-measurable targets that promote confidence and personal development), are seen to contravene the business plans (closely linked to Learning and Skills Council funding) of many 
colleges of further education, or to a creative re-interpretation of what constitutes a viable course by today's criteria. For example, many ESOL and Literacy courses are embedded in vocational low-level NVQ programmes to ensure Learning and Skills Council funding.

\section{Comparing approaches to learning and teaching in adult and higher education}

Teaching at the University of Birmingham did not seem to me to start from where students were. It did not seek to change someone so that they could change the world in that Freirean critical pedagogical tradition that had shaped my approach to teaching and learning in adult and further education. The culture at the University of Birmingham reminded me of the one that I had experienced at the University of Sheffield where I had studied in the 1980s. In general, the learning and teaching methods that are favoured by pre-1992 universities tend to be teacher-centred and focused around an 'I-It' dialogue, rather than the more grounded 'I-You' type of interaction between teacher and student (Goleman 2006). This does not imply that all tutors in pre-1992 universities only use teacher-centred methods, but, rather, that the assumption is still largely that a highly achieving intake of students (usually with a minimum of 2 As and 1 B at 'A' level standard) are academically capable of coping with new information and are autonomous enough to make sense of their own learning and transfer it into acceptable outcomes. What I am suggesting is that pre-1992 universities, unlike the ex-polytechnics or ex-colleges of Higher Education (such as the University of Worcester where I work at present), have not had to deal with the challenge of turning the prior underachievement of their students into academic success, and that, therefore, adult education methods of empowerment have not been regarded as necessary in such universities. In that sense, I felt that pre-1992 universities had not changed in how they viewed students from when I was at the University of Sheffield in the 1980s.

The most prestigious pre-1992 universities benefit from an educational culture or system based on the power to pay for the few more than on the power to learn of the majority. Their research excellence 
means that they are also funded better than those universities with less affluent intakes (see Skelton 2006). Many of the students come from very privileged backgrounds, which may lead them to perpetuate the belief systems of those who are rich and white and have more power than those who are not. However, as I will demonstrate later through my post-course reflections, this does not necessarily mean that such students are 'empowered' to think for themselves. The education system in general and even more so in pre-1992 universities, remains quite conservative and didactic even if the academic results are outstanding. This kind of education system is best described by Freire:

Instead of communicating, the teacher issues communiqués and makes deposits which the students patiently receive, memorize, and repeat. This is the 'banking' concept of education, in which the scope of action allowed to the students extends only as far as receiving, filing and storing the deposits. They do, it is true, have the opportunity to become collectors or cataloguers of the things they store. But in the last analysis, it is the people themselves who are filed away through the lack of creativity, transformation, and knowledge in this (at best) misguided system (1996: 53).

As a critical pedagogue, I hold similar views to those expressed by Burbules and Berk: 'Critical Pedagogues are specifically concerned with the influences of educational knowledge, and of cultural formations generally, that perpetuate or legitimate an unjust status quo; fostering a critical capacity in citizens is a way of enabling them to resist such power effects' (1999: 45). For me what is important is to pose the challenge along the lines advocated by Paul Chatterton: 'It is a call to re-energise the links between education and freedom and empowerment; and it is a challenge to those academics who have become counselors for neoliberal policy and the status-quo, especially inside the university, to look again at how they have retreated from naming and also importantly confronting oppression’ (2007). 


\section{Experience in higher education}

Having been through higher education myself, as a post-graduate student reading linguistics in the 1980s, then, for about 6 years, as a postdoctoral researcher, lecturer and finally teacher trainer, I knew that the methods of teaching that I had experienced were not as empowering as the methods that I had witnessed being employed in a variety of further and adult education institutions, and that higher education lecturers still tended to 'lecture' in the full sense of the word. I had experienced in the previous two decades a variety of higher education institutions, a mix of top performing and not so well performing universities, either in parallel with my further and adult education teaching or when I was having breaks from those sectors. With hindsight, I consider myself lucky to have been in a position to experience so much diversity, in different locations and with different degrees of status. It has made me aware of the strengths and weaknesses that exist in both further and adult education and higher education teaching methods and related practice.

\section{Experience in adult education applied to higher education}

In the spring term of 2006, I decided to use adult education teaching methods at the University of Birmingham. I wanted to empower students to be critical and to develop their own creative knowledge but also to find ways to motivate them to learn about sociolinguistics. The students were not too keen on their compulsory language foundation course as they considered it to be irrelevant to English Literature, which was what they were majoring in after all. The topics that I had to expand on with them in the weekly seminars were around sociolinguistic issues concerning English as an international language, language and imperialism, language and racism, narrative structure, text analysis, bilingualism, social class and the school system. The methods I used with the students were typical adult education methods used for the development of the basic skills of literacy, numeracy and ESOL in community education programmes and included role plays, discussion panels, presentations, creative writing and biographies. In addition, I ensured that all these techniques were underpinned by 
small group/collaborative work to get the students to learn together and from each other.

\section{Adult ESOL methodology and practice}

In adult and further education contexts, the methodology for teaching ESOL (English for Speakers of Other Languages) is very much centred around humanistic approaches, ranging from the Freire model of the 1970s to the present Skills for Life Strategy $(2001)^{1}$ and the Success for All Strategy (2002) ${ }^{2}$. Current approaches have a student-centred emphasis on responding to individual students' levels and learning needs (or differentiation), inclusion and empowerment. Miriam Zukas and Janice Malcolm (2007) argue that adult education has a lot to offer higher education in terms of conceptualising learners and teachers as persons in the world in that Critical Adult Education tradition of starting with the learners rather than with the discipline. Adult ESOL teaching and learning, in particular, always aims to equip students with the necessary skills to use the language outside the classroom and, consequently, improve their chances of survival in the United Kingdom. Jane Jordan, whose book on ESOL teaching influenced countless ESOL practitioners throughout the 1990s, encourages teachers to use strategies that promote learner independence.

Students should be encouraged to take advantage of, or create, opportunities to use English outside the class. You could begin by role playing situations such as joining the library, or obtaining information from an agency or place of entertainment, and sending students out to undertake specific tasks in pairs or individually. News items discussed in class could be followed up at home using task sheets, or students could undertake projects which require finding out information from a variety of sources and making oral presentations (1998: 104).

The emphasis in ESOL classes is for student-centred (never tutor-centred), collaborative/small group work leading to group action/practice that ensures that students learn from each other all the time. This student-centred collaborative learning approach also extends to all 
elements of teaching and learning, including planning, tutoring and assessing. As a teacher trainer, I am not comfortable basing teaching assessments solely on individual teaching and learning, and, in my experience, inspectors rarely give very good grades to teaching sessions in adult or further education in which student-led group work and empowerment, as well as inclusion, are not in constant evidence throughout. In a keynote lecture to the annual Skills for Life conference (2007), Helen Sunderland, Head of the Language, Literacy \& Numeracy (LLU + ) Unit at South Bank University, convinced her audience that the methods of the 1970s are coming back full circle, as the poles of 'best practice' keep being moved every decade or so to accommodate the politics and ideology of the moment. In terms of ESOL curriculum development, for example, new materials clearly rooted in a Freirean approach and encouraging reflection between teacher and students in order to produce democratically negotiated outcomes or actions have made their appearance in the 21st century (see Reflect at < http://www.reflect-action.org/enghome.html >). In the context of higher education teaching, ESOL teacher trainers have also published reflections about critical pedagogy and transformative education, which encourage dialogue between teacher and student about real-world issues, but, as two of them argue: 'In general ES/FL (English as a Second or Foreign Language) teachers have not been encouraged to address sociopolitical issues that educators like Freire (1970) have placed within the heart of educational purposes' (2007: 1). In a study of feminist/critical pedagogy for Japanese as a Foreign Language, Ohara, Saft and Crookes argue that teachers need to 'engage students in dialogue that will give them the opportunity to understand how use of the language being studied contributes to the oppression of women, minorities, or classes' (Crookes and Lehner 2007: 3).

\section{ESOL at present}

Through a promotion of a student-centred ethos, the ESOL tutor is trained to negotiate a syllabus with the students, vary the teaching and learning methods and use materials that are relevant to the students' experience of the world. The Adult ESOL Core Curriculum, which was introduced 
shortly after the Skills for Life strategy of 2001 and is the ultimate guide for all ESOL teachers nowadays, mentions the need for ESOL teaching approaches to take into account, among other things, 'the learners' shortterm goals and the contexts in which they will need to use English', 'the local community context' and 'the need to move learners towards independence' (DIUS 2001: 5). The Core Curriculum uses the term 'learner' rather than 'student' (which has also become the preferred term in adult education in recent years) in recognition that learning takes place in a variety of contexts and not just as a result of teaching in the classroom. The term 'learner' also emphasises the 'lifelong' element of learning, whereby an adult carries on growing and thereby learning throughout their life. There has also been a push for research on aspects of teacher education by bodies like the National Research and Development Centre for Adult Literacy and Numeracy (NRDC), set up in 2002 to encourage and disseminate practitioner research in Basic Skills and based at the Institute of Education, London. The above-mentioned Reflect materials for ESOL are promoted on their web site < http://www.nrdc.org.uk/index.asp $>$. Worth mentioning too is the National Institute for Adult and Community Education (NIACE), a campaigning body for Adult Education based in Leicester (< http://www.niace.org.uk/ >). In addition, there has also been a very recent return to the teaching of pedagogical skills, not just subject knowledge, in all ESOL teacher training programmes, with the publication of new Standards and Qualifications for teachers in the Lifelong Learning Sector (2007), 'Lifelong Learning' being the new name for further and adult education. ${ }^{3}$ These standards make explicit the links between the three disciplines of ESOL, Literacy and Numeracy, and pedagogy in a way not seen in the training of Basic Skills teachers since the late 1980s. Teacher trainers can once again teach aspects of critical pedagogy explicitly and encourage their trainees to engage in critical reflections that stimulate transformatory learning and may lead to positive actions being taken in their professional practice.

\section{Who are the ESOL students?}

The 20 higher education students that I found myself teaching were almost uniformly from very privileged socio-economic backgrounds. 
Only two of these students were minority ethnic and came from a local Birmingham comprehensive school. The rest came from grammar or private schools. This kind of homogeneity was an issue that I had not encountered previously when I was a teacher of adult ESOL in adult and further education. My classes used to be filled with very diverse groups of students from all over the world, some very highly educated (doctors, teachers, etc.) and some with no experience of education and with very strong literacy needs, including in their own mother tongue. Some were from middle class backgrounds and some were not or were from poor rural backgrounds. ESOL classes typically have large intakes of refugees and asylum seekers, migrant workers and settled U.K. immigrants who have missed out on education for socio-economic or cultural reasons. For example, many Pakistani, Indian and Bangladeshi women, originally from rural backgrounds, attend classes to be able to help out with the education of their own children or to better themselves and be able to compete economically alongside men and other women. In his book, 'Adult Literacy: Master or servant, A case study from Bangladesh', James Jennings states:

The group that has had the least access to education is the rural woman. The literacy rate of rural females is $16 \%$ lower than that of their urban counterparts and $35 \%$ lower than that of urban males. In some villages it is difficult to find even one woman who has finished primary school (1990: 97).

An ESOL class will typically encompass all kinds of people with all kinds of 'baggage' and the issue of student empowerment is absolutely key if the tutor wants the students to achieve. At the university, however, the contrast was marked and I was confronted with what I decided to call 'elite students' (high-achieving undergraduates, most of them from very privileged backgrounds). I felt from the start that these students needed to question their beliefs and transform their perceived reality of being the 'regurgitators' of conservative academic practice. These students reminded me of myself, and appeared to be victims of the 'banking' system of education that I, myself, had encountered as a student in higher education. Had I not been through adult 
education, further education and community-centred programmes of Adult Literacy and ESOL, I may not have been so critically aware of the power of the banking system of education.

\section{Adult education methods used in facilitating sociolinguistics learning}

Drawing from the work of Freire (1996) and bell hooks (1994), I posed myself the question: 'How do I teach for challenge and change?' and I had numerous critical dialogues with academic colleagues/friends and trainee teachers of ESOL who encouraged me to teach in the way I had always taught in adult and further education, but to conduct critical reflections afterwards and put them into practice via researching, writing and presenting at conferences. One key C-SAP paper I read by one of my critical friends inspired me to look at current sociological research about race and racism teaching. In the published version of the paper in question, Shirin Housee argues:

The issue of silence and guilt by white students has come up a number of times in this research, however what is interesting is the shift of this dynamic as the classroom becomes more diverse and multi-ethnic (2006: 87).

This led me to look at how an elite group of students, who also happened to be mostly white, would react to issues around language and racism and I was very aware of the need to counteract their potential silence with activities that would get them to exteriorise their beliefs and feelings and learn to critique the world they were being brought up in (Warmington 2007). Another critical friend encouraged me to read more around the theory of critical pedagogy. Joyce Canaan's powerful opening statement, in which she says, 'This paper is part of my own "adventure in unveiling"' (2006: 73), got me to read Freire again and I felt a renewed hope that a progressive education option is still possible today. All these emotionally charged statements from academic friends were in line with what I was also discovering through my reading about the different kinds of pedagogies within the wider field of critical pedagogy. What Sarah Amsler (2007) calls a 'pedagogy 
of hope' inspired me to put pen to paper about issues that I had erroneously thought were not worth publishing.

Following my experience of teaching at the University of Birmingham, I began to research and write about Teaching and Learning more than I had ever done before. I also became an active member of two groups set up by the Higher Education Academy Subject Centre for Sociology, Anthropology and Politics (C-SAP), 'Critical Race Theory' and 'Critical Pedagogy', and I contributed to three of their conferences. I presented a paper based on the theme of this article at C-SAP's international 'Teaching Race' conference in New York in March 2007 (Kadi-Hanifi 2007). The conference provided a forum for scholars from various disciplines in the social sciences and from education to come together and critically report on the teaching of race and ethnicity to undergraduates. My paper received positive feedback from many sociologists from both the United States and the United Kingdom. I was then invited to contribute to two other C-SAP conferences at which I began to realise that the implications of my research on the use of adult education methods to encourage privileged students to become critical thinkers were of interest to those colleagues who teach sociology, anthropology and political science, and not just to those teaching linguistics or education as I had previously assumed.

Negotiation of a learning and teaching programme with a group of higher education students

So there I was, armed with lots of teaching and learning experience, lots of ideas from books, papers, students and friends. I started by asking the 20 undergraduate students on my course two questions:

- What is it that you want to learn?

- How do you want to learn?

The students were obviously not used to being asked their opinion about their own learning needs and they were initially slightly suspicious of my motives. Eventually, the more confident ones in the group started talking and this gradually encouraged others to join in the 
discussion. I was not expecting straight answers to my two questions but rather a feel for what the students expected from this particular course and from the university in general. I got to hear about some of the frustrations that they were experiencing and the issues that emerged from that initial session with them can be summarised as follows:

- Bored with the course in that it can be too theoretical

- No point in doing Linguistics if one is majoring in Literature

- Lecturers were either too strict, unclear or too 'stuffy'

- Too much reading and testing involved

When I asked them what seminars they liked best, they seemed to favour the ones that were very interactive and innovative. For instance, one of the lecturers had used the voice of her own baby when teaching them about first language acquisition. I realised very soon that the students needed more emphasis on experiential learning as they were more than able to extrapolate on the theory behind how language works, and that, therefore, I would steer clear from boring them with long seminars on theory. The Kolb cycle (1984), as taught on teacher education programmes for adult and further education, was looming large in my mind. It is mainly about learning experientially and then reflecting on the experience before conceptualising it.

Bearing all this in mind, as well as Maslow's hierarchy of needs (1943), which is also very much used in teacher education programmes for adult and further education and which consists of making sure that self-actualisation and the basic needs of one's students are met, I guess I was listening to the students with a keen ear. These 20 university students had strong needs for experiential, enjoyable learning sessions. One of them said: 'We had fun and enjoyed ourselves' when they were recounting to me the baby language recording that one of their lecturers had used. I set out to replace the often ethnocentric teacher-centred and textbook-centred methods typically used on linguistics courses in pre-1992 universities with the following: 
- Student panels to debate major sociolinguistic concepts like language and racism and language and imperialism

- Role plays and presentations to take away the fear of having to express a controversial opinion

- Creative writing homework for a Critical Discourse Analysis approach to text analysis and narrative structure as these were Literature students who loved to experiment with text and attached great value to the aesthetics of writing

- Literary texts and essays on language by non-white authors to expose the students to other world views from the perspective of the 'oppressed'

\section{Methods and resources used to facilitate learning and teaching}

When we talked about the phenomenon of English as a world language and its rapid expansion all over the world, I wanted the students to experience this through the eyes of some of the leading African and Asian writers on the subject. The students had never read English Literature written by African authors and could not name one single black African writer. David Crystal's book on the English Language (2002) provided the students with a starting point for exploring how a new world English (or WSSE - World Standard Spoken English) may be emerging, influenced for the first time in the modern history of the English Language by the languages of people in non-first world countries like India, Nigeria, Singapore (and where English is not the first language). Crystal suggests that British, American or Australian English may be superseded by a more global WSSE (pronounced 'woossie') based on the languages of emerging economies where it is already taking root. In this particular seminar, I gave the students three passages written by two African writers and one British Indian writer. They were asked to read these passages first and briefly discuss the gist of the argument presented by each writer with me, before proceeding to the activity that I planned for them and which consisted of panels arguing for and against English as a global language.

I presented them first with a passage from Chinua Achebe's acclaimed classic novel 'Things fall apart' (1958), which they read in pairs in order to find all the expressions to do with Nigerian English. The pairs read the script as actively as possible and under- 
lined words or phrases that they did not quite fully understand and which I explained to them using the glossary at the end of the novel. The students were fascinated by this text and by the beauty of this type of English. We then discussed how English can express an African reality and how we can also learn from an English Literature written by non-white authors. The passage is reproduced below:

\section{Chinua Achebe}

'I feel that English will be able to carry the weight of my African experience.'

An excerpt from his novel Things Fall Apart:

'Go to your in-laws with a pot of wine and beg your wife to return to you. It is not bravery when a man fights with a woman'. He turned to Odukwe, and allowed a brief pause.

'Odukwe's body, I greet you,' he said.

'My hand is on the ground,' replied Odukwe.

'Do you know me?'

'No man can know you', replied Odukwe.

'I am Evil Forest, I am Dry-meat-that-fills-the-mouth, I am Firethat-burns-without-faggots. If your in-law brings wine to you, let your sister go with him. I salute you'. He pulled his staff from the hard earth and thrust it back.

Then, the students looked at Salman Rushdie's reflections (in Crystal 2003) on Indian English. They related this to the passage by Chinua Achebe and debated with me how post-colonial commonalities between India and Nigeria had led to a transformation of British English into Indian English and Nigerian English. This way, the language that was perceived in the past to have perpetuated racism and imperialism against third world peoples had been re-fashioned to fit with the realities of post-colonial countries and to represent their views more equitably. I was able to introduce the students to the key sociolinguistic concept of 'change from below', which sociolinguists like Labov (1972) and Milroy (1981) had applied to Black American English and to Belfast working-class English, respectively, but which I was now 
also applying to the potential in the third world to change the English language at a more global level.

\section{Salman Rushdie}

I don't think it is always necessary to take up the anti-colonial - or is it post-colonial? - cudgels against English. What seems to me to be happening is that those peoples who were once colonised by the language are now rapidly remaking it, domesticating it, becoming more and more relaxed about the way they use it. Assisted by the English language's enormous flexibility and size, they are carving out large territories for themselves within its front.

Finally, the students and I examined an alternative to Salman Rushdie's and Chinua Achebe's views of the desirability of English Language change to accommodate the realities of Africa and India. Ngugi wa Thiong'o believes that getting rid of English in post-colonial Africa is key to true 'decolonisation' (1986). I used the extract below for this particular seminar.

\section{Ngugi wa Thiong'o}

In the 20th C Europe is stealing the treasures of the mind to enrich their languages and cultures. Africa needs back its economy, its politics, its culture, its languages and all its patriotic writers. This book is my farewell to English as a vehicle for any of my writings. From now on it is Gikuyu and Kiswahili all the way.

Then I organised a debate between the following positions:

- For English as a global language: language as a vehicle or a tool for expressing a non-white reality

- Against English as a global language: language and imperialism, language and racism

After a degree of negotiation, the students formed two opposing panels to role play and then present the arguments they had come 
up with as a group. The two opposing student panels each had to nominate one member to represent their views to the opposite group and they were under strict instructions to fight for their cause and convince the opposing panel. The rest of the students on the panels could add to what their representatives were saying, particularly if the opposing panel challenged an argument or asked a question to clarify what was being said.

A degree of competition was embedded in this activity by asking the students to play their role so well that they would convince everybody that their panel was the best. After much preparation, rehearsing and choosing who would speak for them, the students eventually played the opposing panels and I noted down all of their views on a whiteboard in two columns, 'pro' and 'against'. This action seemed to encourage them to perform better as the words they used were given credibility by being written on the whiteboard. I was not the one with the power to teach anymore but rather the one recording the power of their argument.

What is important when using role play is to give strict guidelines to those who are asked to act a role, followed by at least one chance for them to rehearse the acting by themselves (or when used in small groups, to rehearse with each other). Also crucial to role play is for the teacher not to interfere beyond giving out the briefs and the instructions to the different players. Role play as a teaching technique is also very useful in controversial topics as it helps to move students away from expressing their own possibly 'biased' perspectives, as they have to concentrate on playing a role rather than exposing their true views. Learning and knowledge are therefore created 'despite the views held' or without 'feeling guilty/embarrassed in the company of peers' as a great ESOL teacher I admired, Jill Manley, used to say. What I wanted to achieve was collaborative work among the students in order to inspire them to want to know more and then read more about the basis of and the challenges to the supremacy of British English. By doing it this way (rather than giving them some of the answers via a seminar or lecture), I was trying to help them create their own knowledge and thereby own it. 


\section{Bilingualism, social class and the school system}

When we then looked at the topics of bilingualism, social class and the school system, I asked the students to present biographies, based on their own experience or the experience of someone they knew, on how teachers showed prejudice against minority languages or social dialects. The profile of the biographies produced by the students was 'spiky' (to use an ESOL jargon word that describes the typical diverse nature of ESOL students' levels of work) in that it ranged from teachers discriminating against working class, dialect speakers, to discriminating against ethnic minority children and upper class speakers. Then the students read Le Page and Tabouret-Keller (1985), Bernstein (1970-1990) and Labov (1972) to learn more about discrimination against minority ethnic speakers, social class and educational bias and the logic of non-standard English, respectively.

A seminar consisting of 5 to 10-minute role plays addressed the following key question: 'Do you think that there is evidence to support the view that middle class children achieve better at school?' The pairs played to the two opposing views on language, i.e., Labov vs. Bernstein, in that one student would speak in non-standard English (or slang if they preferred) and the other in standard English, on a topic of their choice, whilst the rest would listen to the dialogue and then rate it for how logical it was. I had previously introduced the students to some of the recordings Labov had made in New York. I chose to focus on the work he did with gangs of youths, as I felt that the students would identify with his work on younger more than on older age groups. I wrote examples of non-standard African-American language on the whiteboard from the data he had collected in 1972 - things like 'I ax Alvin do he know how to play basketball'. A debate ensued in terms of how logical non-standard English was and how complex in structure it could be. In the examination of attitudes to language, class and ethnicity that followed, the students were able to articulate their views without fear, particularly those who had had to speak in non-standard English, like Labov's New York gangs, and those who had had to defend its logic to those who did not speak it. This was an example of how role play can help re-conceptualise what 
was learned before. In this case, those observing the pairs and rating their language in terms of logic were expressing what sociolinguists such as Labov (of the Critical Discourse Analysis tradition) have said about the power of Standard White American English.

\section{Narrative structure and text analysis}

When looking at narrative structure and text analysis, I asked the students to write creative pieces exploring what they had been learning with me over the weeks. The students wrote beautiful fictional prose related to incidents that they imagined could have happened over the weeks, including two key pieces in which two students describe clashes between a professor of English Literature, who they found intimidating, and me. In one of the pieces, the student wrote:

... before anyone knew, Karima had been abducted by the psychotic professor ... 'give me the lecture notes' ... just as it looks as though Karima's time up, [my student's name] leaps from his chair, releases his fountain pen with wicked pace and precision. The pen catches [professor's name] in the eye and he falls out dead.

Another student wrote:

... [professor's name] opened the door and through the thick mist emerged a tall cloaked figure. It was the linguistic giant Labov closely followed by a posse of urban gangsters ...

The students enjoyed this piece of homework and shared it with the others. To me, it felt as if the students were recognising the legitimate place of Sociolinguistics in Literature by the literary, textual embedding of the subject in what they loved to do best - which is to play with language and text. The students' writing also showed some of the tensions between Literature and Linguistics, which the students, I guess, were never empowered to voice before; the academic expectation had always been that they just had to go through the language foundation course and not complain about it. 
The text analysis was not done by me for the students, but by them for me and for each other and the tensions between the two disciplines of Literature and Linguistics were discovered by the students themselves, as they analysed each other's writings. This, I felt was a powerful example of creative knowledge and the reading, mainly around Critical Discourse Analysis, which I gave them to take away and apply to the knowledge that they had already acquired for themselves, was made a lot easier and entertaining than it used to be in my days. Then, for example, we were given endless theoretical readings to do, instead of experimenting with our own language, and therefore our own capabilities, first.

\section{Conclusion}

In some ways, I realised that, although these were supposedly 'elite', high-achieving students, they were utterly disempowered to change their own condition. I realise now that the term 'elite', a construction and a label that I had attached to these students because of their economically privileged backgrounds, had made me assume that they would have power and would perhaps even be deliberately racist and discriminatory. As it turned out, I discovered that these students were just waiting to be motivated enough and their imagination fired up by learning and teaching methods that promote critical, transformatory learning (Johnson-Bailey and Alfred 2006). My students had had an enjoyable learning experience, discovered concepts by themselves that led them to want to know and read more (especially books from the black experience and on the 'wider world') and, more importantly, transformed themselves even if only in small ways. I had learned more about the many facets of oppression in education and my journey from being a student then teacher in higher education first, to being a teacher in further education, adult education and now higher education again, made sense. I had applied what I had learned about learner engagement perspective in all those ESOL classes that I had taught and now I wanted to learn a lot more as I carried on along the path of critical pedagogy. 
The approach that I have highlighted in this paper can be and indeed has been used in other disciplines. Critical Pedagogy methods that are transformatory and based on innovative approaches that are empowering to the student and to the teacher, are regularly being promoted by progressive higher education teachers. In Sociology teaching, for example, student debates and discussion panels sparked off by the use of films (see Spencer 2006 and also Housee 2007) and student-centred projects (see Horowitz 2006) have been successfully used to connect current issues in society to theoretical debates. In terms of pedagogic theory and reflection, Amsler and Canaan (2008) have written a theoretical reflective article on the constraints and possibilities of using Critical Pedagogy in Sociology. A new master's degree in socio-political activism and social change has recently been introduced at the University of Leeds (Chatterton 2007). Feminist Pedagogy approaches that promote co-operative learning and resources that are less western-centred, such as those highlighted by Welch (2006), offer possibilities to engage with the students in a critique of neo-liberal values. What certainly stands out for me as a critical pedagogue (engaged in both academic and activist pursuits) and has contributed to the drive I have to work in an inter-disciplinary, reflective and empowering way with academics, students, practitioners and grassroots communities is the C-SAP Critical Pedagogy Weekend of 2007. It brought together higher education practitioners (from the disciplines of Sociology, Sociolinguistics, Education and Geography), Adult Education activists (Banner Theatre and the Workers' Educational Association that both use Popular Education), two Popular Education practitioners from Venezuela and higher education Sociology students who presented papers on an equal footing with established academics. One of the immediate effects of such a 'critical' weekend on me as a current higher education practitioner was to introduce Popular Education methods as credible tools for teacher education. I have recently experimented with kinaesthetic methods (from Feminist Critical Pedagogies used in South America, as in Nadeau 1996) that use the whole body in order to enhance empathy levels in teachers of Literacy and ESOL by getting them to experience some of what their adult learners feel. 
Furthering the 'praxis' part of the Freirean approach is where I need to go next in my research on progressive teaching and learning approaches in higher education. The specific aspects of praxis described in this paper - negotiating the syllabus with students, group analysis of carefully selected texts, role play - could be used on Sociology, Anthropology and Political Science courses and linked to the research and practice on progressive feminist, anti-racist teaching and learning research that is already out there in these disciplines. I believe that by working together we can change the world and that Critical Pedagogy (using student-centred Popular Education methods) is what should be at the heart of all teaching and learning that has social change and transformation as its main aim.

\section{Acknowledgements}

Thanks to Vince Russel, John Keenan and Shirin Housee for their invaluable help in the early stages of writing this article.

Karima Kadi-Hanifi has been teaching in further, adult and higher education, in the areas of ESOL, Literacy, Teacher Education, Linguistics and Sociolinguistics since 1986. She is Senior Lecturer in the Institute of Education, University of Worcester, training Post-Compulsory teachers of ESOL and Literacy and coordinating initial teacher education programmes in Further Education colleges for the university. Her recent research has been in the area of critical pedagogy and anti-racist teaching and learning, and she has presented three papers at C-SAP conferences, one of which has led to this article. Her PhD research was in the area of language and social class at the University of Sheffield.

Contact: Institute of Education, University of Worcester, Worcester, WR2 6AJ, U.K. E-mail: k.kadi-hanifi@worc.ac.uk 


\section{Notes}

1. The Skills for Life Strategy of 2001 can be found on the web site of the Department of Innovation, Universities and Skills, http://www.dfes.org.uk/ readwriteplus/

2. The Success for All Strategy of 2002 provides increased funding from the government in a quest to improve the quality of learning and teaching in further education. Details can be found on the web site of the Department of Innovation, Universities and Skills, http://www.dfes.org.uk/readwriteplus/

3. The 2007 Standards and Qualifications for teachers in the Lifelong Learning Sector (2007) can be found on the Lifelong Learning UK web site, http:// www.lluk.org/2799.htm

\section{References}

Achebe, C. (1958) Things Fall Apart, London: Heinemann.

Amsler, S. (2007) 'Towards a sociology of hope: critical education research as praxis in academe, Discourse, Power, Resistance', paper presented at the C-SAP Critical Pedagogy Weekend, Birmingham, 30 November - 2 December.

Amsler, S. and Canaan, J. E. (2008) 'Whither critical pedagogy in the neo-liberal university today?' ELiSS 1, no. 2.

Bernstein, B. (1970-1990) Class, Codes and Control, 4 vols. London: Routledge.

Burbules, N. C. and Berk, R. (1999) 'Critical thinking and critical pedagogy: relations, differences, and limits', in T. S. Popkewitz and L. Fendler (eds) Critical Theories in Education, New York: Routledge, 45-65.

Canaan, J. E. (2006) 'Teaching social theory: Reflections from a teaching diary', in J. Cope, J. E. Canaan and D. Harris (eds) Learning and Teaching Social Theory, Birmingham: Higher Education Academy Subject Centre for Sociology, Anthropology and Politics (C-SAP monograph) no. 8, 73-97.

Chatterton, P. (2007) 'Using Geography to teach freedom and defiance. Lessons in social change from "Autonomous Geographies”, paper presented at the C-SAP Critical Pedagogy Weekend, Birmingham, 30 November - 2 December.

Crookes, G. and Lehner, A. (2007) 'Reflections on an ESL critical pedagogy teacher education course', University of Hawaii, < http://www.hawaii.edu/sls/ crookes/crit_ped.html > (accessed 19 October 2007).

Crystal, D. (2002) The English Language, London: Penguin Books.

_ (2003) English as a Global Language, Cambridge: Cambridge University Press.

Curzon, L. B. (1990) Teaching in Further Education, London: Cassell. 
Department for Innovation, Universities and Skills (DIUS) (2001) Adult ESOL Core Curriculum, < http://www.dfes.gov.uk/curriculum_esol/ > (accessed 8 May 2008).

Freire, P. (1996) Pedagogy of the Oppressed, Middlesex: Penguin.

Goleman, D. (2006) Social Intelligence, London: Hutchinson.

hooks, b. (1994) Teaching to Transgress, London: Routledge.

Horowitz, E. (2006) “"But everyone hates everyone?” - Using data to depersonalise race discussions in sociology', Proceeding of the C-SAP Teaching Race in HE Social Sciences - What Next? conference.

Housee, S. (2006) 'It's not 'cos I'm black or brown or female: but 'cos I know the stuff of 'race' and racism', in S. Jacobs (ed.) Pedagogies of Teaching 'Race' and Ethnicity in Higher Education: British and European experiences, Birmingham: Higher Education Academy Subject Centre for Sociology, Anthropology and Politics, 73-95.

_ (2007) 'Anti-racist teaching methods', paper presented at C-SAP Critical Pedagogy Weekend, Birmingham, 30 November - 2 December.

Jennings, J. (1990) Adult Literacy: Master or servant? A case study from rural Bangladesh, Dhaka: University Press Limited.

Johnson-Bailey, J. and Alfred, M. (2006) 'Transformational teaching and the practices of Black women adult educators', New Directions for Adult and Continuing Education, no. 109: 49-59.

Jordan, J. (1998) An Introduction to Teaching English as an Additional Language to Adults, London: The Basic Skills Agency.

Kadi-Hanifi, K. (2007) 'Inspiring and empowering privileged students', paper presented at C-SAP Teaching Race \& Ethnicity Conference, New York, March.

Kolb D. A. (1984) Experiential Learning Experience as a Source of Learning and Development, New Jersey: Prentice Hall.

Labov, W. (1972) Language in the Inner City, Oxford: Blackwell.

Leitch, S. (2006) Leitch Review of Skills, Prosperity for all in the global economy - world class skills, London: HM Treasury.

Le Page, R. B. and Tabouret-Keller, A. (1985) Acts of Identity, Cambridge: Cambridge University Press.

Maslow, A. (1943) 'A theory of human motivation', Psychological Review 50, 370-396.

Milroy, J. (1981) Regional Accents of English Belfast, Belfast: Blackstaff Press.

Nadeau, D. (1996) 'Enbodying feminist popular education under global restructuring', in S. Walters \& L. Manicom (eds) Gender in Popular Education, London: Zed Books.

Ngugi wa Thiong'o (1986) Decolonising the Mind: The Politics of Language in African Literature, London: Heinemann. 
Ohara, Y., Saft, S. and Crookes, G. 'Teacher exploration of Feminist/Critical Pedagogy in a beginning Japanese as a Foreign Language language class', University of Hawaii at Manoa, < http://www.hawaii.edu/sls/crookes/crpj.html >, (accessed 2 July 2007).

Petty, G. (2004) Teaching Today, London: Nelson Thomas.

Rogers, J. (1977) Adults Learning, 2nd ed., Milton Keynes: Open University Press.

Skelton, A. (2006) 'Democratising Excellence', Academy Exchange, Issue 7: 17-19.

Spencer, S. (2006) 'Race, ethnicity and cucumber sandwiches: under the skin of teaching race and ethnicity in higher education', workshop at C-SAP Teaching Race in HE Social Sciences - What Next? Conference, London, 27-28 June.

Sunderland, H. (2007) 'Good practice in Skills for Life', keynote lecture at Annual Skills for Life conference, Birmingham, June.

Warmington, P. (2007) 'The 'R' word: Voicing race as a critical problem and not just a problem of practice', paper presented at the Discourse Power Resistance conference, Manchester Metropolitan University, March.

Welch, P. (2006) 'Feminist pedagogy revisited', LATISS - Learning and Teaching in the Social Sciences, 3, no. 3: 171-199.

Zukas, M. and Malcolm, J. (2007) 'Learning from Adult Education', Academy Exchange, Issue 6: 21-22. 